\title{
Targeted Subordination of Official Sector Debt
}

Lee C. Buchheit

G. Mitu Gulati

\section{Scenario One}

Guy walks into his banker's office, sits down and announces "You know, don't you, that I haven't a snowflake's chance of repaying all the money I have borrowed from you over the years?"

"What," gasps the banker in horror, "you came all the way down here to tell me that!"

"Not at all," replies the customer calmly, "I came down here to discuss the terms of a new loan."

$\underline{\text { Scenario Two }}$

Greek guy walks into a negotiating room in Brussels . . .

Financial wardship

As of this writing, Greece has embarked on its third official sector bailout package in five years. The total amount already borrowed under these packages, excluding the financial assistance provided to the Greek banks by the European Central Bank, already approaches $€ 246$ billion. The latest program, if fully implemented, could add as much as another $€ 86$ billion. Greece faces the very real prospect of being the financial ward of its official sector sponsors (the European Union and the International Monetary Fund) for the whole of this decade.

Two things have changed over the last five years. First, Greece's economy has contracted painfully as a result of the fiscal adjustment measures upon which continued official sector assistance has been conditioned. The social and political backlash in Greece is perfectly visible. Second, the sheer size of Greece's public sector debt burden -- now in excess of $176 \%$ of GDP -- is widely recognized as unsustainable. Although the maturities of these loans have quietly been extended for decades into the future, and the interest rate reduced substantially, even the IMF has recently called for further debt relief including a possible write-down of the nominal amount due to official sector lenders apart, naturally, from amounts due to the IMF itself. Discussing massive new loans while simultaneously asking for a write off of the old loans extended by the same group of creditors will test the skills of any debt negotiator. 
Both Greece and its official sector sponsors should wish to end this financial wardship. For Greece, it is a matter of pride and a sense that the country is regaining some control of its financial destiny. For the official sector, pouring in additional money while openly discussing the forgiveness of a portion of the moneyalready-poured-in poses an obvious political problem. The question is how. Greece will certainly need to borrow. If that money does not come from official sector sources, it must come from the private sector. But commercial lenders will be leery of extending new credit to Greece for so long as the risk of a Greek exit from the Eurozone is present. Private creditors will also naturally worry about lending new money to a country carrying a colossal and unsustainable stock of existing debt.

Last spring, when Grexit fears temporarily subsided, Greece was able to borrow in the international bond markets at an annual interest rate of less than 5\%. The market's logic was that by virtue of the maturity extension of the official sector loans coupled with very low interest rates on those credits, the official sector had structurally subordinated itself to any new private sector lending that matured before the official sector credits started to fall due. The buyers of these new bonds had apparently persuaded themselves that the official sector either could not, or would not, accelerate its loans and thus become an unexpected competitor for scarce Greek financial resources in the interim ${ }^{1}$. The trick in the future will be to make a country with a debt to GDP ratio in excess of $176 \%$ presentable to the markets without inflicting an immediate, and politically unpalatable, nominal haircut on that debt stock.

\section{Legal Subordination (“Turn Over")}

Assuming that Grexit worries eventually recede, the official sector lenders to Greece (apart from the IMF, which presumably will wish to stay out of this) could consider formally subordinating their existing claims against Greece, on a

It strikes us as doubtful whether the private markets would again be prepared to accept only a de facto, structural subordination of official sector debt before resuming lending to Greece. Following Greece's failure to make a payment to the IMF on June 30, 2015, the European Financial Stability Facility (EFSF) released a "Declaration of Default and Reservation of Rights" (July 3, 2015). This Declaration noted that an Event of Default had occurred under the EFSF Public Sector Involvement -Liquidity Management Facility Agreement dated 1 March 2012 and stated:

The occurrence of an Event of Default under the PSI Facility Agreement entitles the EFSF, by written notice to the Hellenic Republic, to cancel the Facility and/or declare the aggregate principal amount of all Financial Assistance Amounts made and outstanding thereunder to be immediately due and payable, together with accrued interest. (emphasis added)

The EFSF stopped short of accelerating unmatured principal under this Facility, but expressly reserved the right to do so. In light of this reminder of EFSF's acceleration rights, we suspect private sector lenders will now look for a legal -- not just a structural -- subordination as a condition to new lending. 
targeted basis, to encourage new private sector lending to the country. Ideally, such lending could displace some of the official sector borrowing contemplated by the third bailout program. Perhaps more realistically, however, it could be used to augment the resources available under that program without having to negotiate a fourth bailout or to fund pro-growth initiatives not contemplated by the third program.

Any such subordination would be targeted, meaning that the official sector would need to approve both the terms and the general use of proceeds of any new senior borrowing. This would not be a general subordination in favor of all future private sector lending.

Subordination arrangements come in many forms but this one can be straightforward. The subordination would require that if ever the new (senior) private sector bonds fell into payment arrears, the official sector creditors would turn over to the trustee acting for the bondholders such portion of the payments received under official sector debt as may be necessary to cure the payment default on the senior bonds. The subordination is not a guarantee: if at the time the official sector loans are also in default, the official sector would be under no obligation to indemnify the senior bondholders. The instrument of subordination would need to be governed by the law of a non-EU country to avoid the risk of a subsequent EU directive that undercuts the efficacy of the subordination. The debtor would be asked to agree that any funds paid over to the senior creditors in this way would still be owing to the official sector lenders.

\section{Enhanced Structural Subordination}

The alternative to a full legal subordination with a turn-over feature of the kind described above would be enhanced structural subordination. Under this approach the official sector would open a window (by deferring the maturity of its own loans) into which new private sector lenders could advance credit without fear of competing with official sector lenders when the time comes for repayment. To do this effectively, however, the official sector would need voluntarily to forswear its ability to accelerate the maturity of those loans, whatever the provocation. The structured subordination could be further enhanced by a full debt service holiday on official sector loans for a number of years or by setting the interest rate on those loans very low during the window period. Although the new private sector lenders would not have the comfort of knowing that any payments made to the official sector lenders would have to be turned over to them in the event of a default, they could take considerable comfort from the fact that little, if anything, would be $d u e$ to the official sector creditors during this period. 


\section{The positions of the actors}

The official sector lenders. Official sector lenders can be expected initially to recoil at the word "subordination". After all, these are the same countries that claimed for themselves a preferred creditor status in the 2012 Treaty Establishing the European Stability Mechanism, second only to the preferred creditor status of the IMF. They will see a voluntary subordination in favor of private sector lenders as a long step down from that exalted perch. The charm of a targeted subordination for the official sector -- its only charm -- lies in a sober assessment of the alternatives: (i) lending the money itself with the near certainty that the funds will not be recovered for many decades and a good chance that a portion will never be recovered at all or (ii) immediately writing off a portion of existing official sector loans in order to make the debtor country presentable to the market ${ }^{2}$.

The private market will impose its own discipline on sovereign borrowers and will punish what it perceives as imprudent policies with an immediate basis point penalty. All sovereign borrowers in the public markets are subject to these forces. Although they may not substitute entirely for official sector prescribed fiscal adjustment measures, market discipline can reinforce the debtor's motivation to pursue appropriate policies and perhaps occasionally avoid the need for the official sector to use its heavy fist in enforcing compliance.

The official sector could analyze the situation as follows. There are four possible outcomes were the official sector to subordinate its loans on a targeted basis to new private sector lending:

2 The IMF staff's latest assessment (released on July 14, 2015) notes that:

At the core of this conclusion [that the grace and repayment periods of European official sector debts need to be doubled] is the fundamental premise that public debt cannot be assumed to migrate back onto the balance sheet of the private sector at interest rates consistent with debt sustainability until debt is much lower. Greece cannot return to markets anytime soon at interest rates that it can afford from a medium-term perspective. (emphasis added)

If a debt writeoff is not on the (political) cards, the IMF staff concludes, a "very dramatic extension" of the grace and repayment periods for Greece's official sector (European) debt would be required.

This reflects the basic premise that debt cannot be assumed to migrate back onto the balance sheet of the private sector at interest rates close to the current AAA rates before debt levels have been brought to much lower levels; borrowing at anything but AAA rates in the near term will bring about an unsustainable debt dynamic for the next several decades. (emphasis added)

IMF Country Report 15/186, Greece: An Update of IMF Staff's Preliminary Public Debt Sustainability Analysis (released July 14, 2015). 
(i) Greece pays in full both its official sector and private sector debts.

(ii) Greece defaults on both its official sector and private sector debts.

(iii) Greece pays its official sector lenders but defaults on the new (senior) private sector loans.

(iv) Greece pays its private sector lenders but defaults on its official sector debt.

In both scenarios (i) and (ii) the official sector is a big winner. It will have encouraged new private sector loans -- and thereby displaced the need for additional official sector exposure -- at no cost to itself. This is especially true in scenario (ii) where the defaults occur across the board and would have fallen on the official sector had it lent the additional money itself.

In scenario (iii) the official sector (assuming a full legal subordination) would be obliged to turn over a portion of the funds they receive to cover a default on the senior private sector debt. But that will simply result in those turned-over amounts still being due to the official sector and the whole premise of this scenario is that Greece has decided to continue paying its official sector debt in full.

Scenario (iv) would not require the official sector to turn over any funds to the private sector. The official sector lenders are only prejudiced in this scenario if the size of the new senior private sector debts has grown so large that they consume resources that would otherwise have been used to pay official sector debts. Of course, that same strain on resources would presumably also have been present had the new loans come from the official sector in the first place.

The private sector lenders. A prospective private sector lender benefiting from the subordination should view Greece as effectively shriven of the vast majority of its outstanding debt. The official sector debt will still be there, of course, but the terms of the subordination should ensure that the official sector lenders will not be competitors for scarce resources if ever Greece finds itself unable to pay both its senior private debt and its official sector creditors. Outstanding Greek Government bonds now total about $€ 37.7$ billion; IMF credits add about $€ 21.4$ billion (for a total of $€ 59.1$ billion). No subordination would be sought from these lenders. If the other official sector debt is expunged from the Greek balance sheet for credit analysis purposes, this would be equivalent to lending to a Eurozone member with a debt to GDP of less than $35 \%$. 
Greece. Reaccessing the private capital markets, even under cover of a targeted subordination of existing claims, would begin to wean Greece from its status as a ward of the official sector. It would convey a measure of independence, perhaps a measure of dignity, in the public eye.

It would not, however, be costless. The markets will lend to Greece at higher interest rates and shorter tenors than Greece's official sector loans. Moreover, the private lenders will expect to be repaid at maturity and will not hesitate to pursue their legal remedies if they are not. On balance, all of this may be salutary. The principal brake on excessive sovereign borrowing is the realization that the money must eventually be repaid. As noted above, the markets exact their own discipline on sovereign debtors -- all sovereign debtors -- and it is altogether healthy that they do so.

\section{Conclusion}

Encouraging private sector lending to Greece through a targeted subordination of official sector debt achieves certain objectives but not others. It will not obviate the need for additional official sector financial assistance; even in the best case, private lending could displace only a small portion of the needed official sector loans. It will not avoid the need for additional fiscal adjustment in Greece; the markets would demand it even if the official sector did not. And it will not eliminate the eventual need for official sector debt relief although it may help to deflect radical forms of debt relief like nominal haircuts until a more politically auspicious moment. Finally, no amount of subordination will induce new private sector lending at tolerable interest rates until the risk of a Greek exit from the Eurozone subsides.

Between May 2010 and March 2012 (when Greece executed a restructuring of what remained of its bond indebtedness), the official sector allowed Greece's private sector creditors to exit a distressed situation entirely unscathed. Those liabilities migrated, at par, from the hands of the people who lent the money into the hands of taxpayer-funded official sector creditors. It was a policy now almost universally regretted. Encouraging private capital flows back into Greece should be a priority of the official sector. 